\title{
Effectiveness of Intra- Aortic Ballon Pump (IABP) Insertion as Rescue Mechanical Support for on Pump Coronary Artery Bypass Surgery Patients with Persistent Intraoperative Hemodynamic Instability.
}

\author{
Harish $\mathbf{R}^{1}$, Rajitha $\mathrm{A}^{2}$, Kodandapani $\mathrm{C}^{3}$ \\ ${ }^{1}$ Associate professor, Department of Cardiac Anesthesia, Narayana Medical college \& Hospital, Nellore, ${ }^{2}$ Assistant Professor, Department of \\ Anaesthesiology, Narayana Medical college \& Hospital, Nellore, ${ }^{3}$ Consultant CTVS surgeon, Department of Cardiothoracic and Vascular Surgery, \\ Narayana Medical college \& Hospital, Nellore.
}

\section{Abstract}

Background: Aim: Aim of this study was to evaluate the efficacy of IABP as a rescue mechanical support intra-operatively in persistent hemodynamic instability in a group of patients who have undergone elective CABG surgery. Subjects and Methods: It is a retrospective study conducted on patients who have undergone on pump CABG and received rescue IABP support intraoperatively. The IABP was inserted in the presence of hemodynamic instability as a rescue, inserted percutaneously via right or left femoral artery approach. Results: There is a marginal increase in the duration of mechanical ventilation $68.99 \pm 30.93$ hours and duration of ICU stay $5.97 \pm 1.93$ days. All patients had significant ST-T changes in more than 2 leads. No major complications related to IABP were recorded. An echocardiogram shown significant improvement in EF ( $\mathrm{p}$ value $=<0.0001$ ). No in-hospital and 30 days mortality was recorded. Conclusion: This study shows significant improvement in hemodynamics post IABP insertion; improvement in EF at discharge from hospital and no mortality at discharge from hospital and 30 days postoperatively. IABP also decreased the postoperative length of stay. Preoperative IABP suggesting that it is effective in patients with severe LV dysfunction undergoing OPCAB.

Keywords: Intra-aortic ballon pump, Coronary artery bypass, Mechanical ventilation, Echocardiogram.

Corresponding Author: Dr. Rajitha A, Assistant professor, Department of anaesthesiology, Narayana Medical college \& Hospital, Nellore.

Received: August 2019

Accepted: August 2019

\section{Introduction}

The use of IABP counter-pulsation in various clinical scenarios recently has become controversial. ${ }^{[1-3]}$ In light of the debate initiated by high-quality randomized controlled trials (RCT) and subsequent comprehensive meta-analyses, both North American and European guidelines have downgraded the use of the IABP from a class I to a class II recommendation. ${ }^{[4-9]}$ Some RCT showed a survival benefit with IABP insertion for coronary artery bypass grafting $(\mathrm{CABG})$ patients with low Ejection Fraction(EF). ${ }^{[10,11]}$ Also, it has been clear that IABP is an effective means of supporting failing circulation in patients at high risk of cardiovascular events postoperatively. ${ }^{[12]}$ The prophylactic use of IABP has been shown to reduce in hospital mortality in patients with left ventricular (LV) systolic dysfunction undergoing CABG by meta-analysis of RCT. ${ }^{[13]}$ Several authors have demonstrated the safety and efficacy of perioperative IABP support in patients undergoing either elective or urgent $\mathrm{CABG}$ with severe $\mathrm{LV}$ dysfunction. ${ }^{[14-16]}$ The aim of this retrospective analysis was to evaluate the efficacy of IABP as a rescue mechanical support intraoperatively in persistent hemodynamic instability in a group of patients who have undergone elective CABG surgery.

\section{Subjects and Methods}

It is a retrospective study conducted on patients who have undergone on pump CABG and received rescue IABP support intraoperatively at our center between March 2017 to November 2018. Since this is a retrospective study, the consent was already taken for surgery and IABP support. The study was approved by local ethics committee.

Selection and description of participants: Of the total 496 CABGs performed between the period March 2016 to November 2017, 40 patients who had rescue IABP support intraoperatively were included in the study. The preoperative risk assessment was analysed with EuroSCORE II scoring system and patients were categorised accordingly [Table 1]. Intraoperatively, hemodynamics just before IABP insertion and following IABP insertion at specified time intervals (15 minutes, 1 hour, 6 hours and 24 hours), Transesophageal Echocardiography(TEE) findings in terms of EF,new onset regional wall motion abnormalities (RWMA),ST-T changes on Electrocardiogragram (ECG), no.of vasoactive drugs with dosages were analysed [Table 2]. Postoperatively, duration of IABP support, duration of mechanical ventilation, length 
or Intensive Care Unit (ICU) stay, no of transfusion of blood and blood products, mortality and any complications related to IABP support were analysed. [Table 3]

\section{Operative technique:}

All patients were operated by single surgeon who has 10 years of experience in cardiac surgery. All surgeries were performed by using Cardiopulmonary Bypass (CPB) after full heparinization.Technique used was moderate hypothermia $(30 \mathrm{oC}-32 \mathrm{oC})$ on arrested heart with antegrade cold blood cardioplegia which was repeated every 20 minutes. The average CBP time was $148.48 \pm 42.3$ minutes and average cross clamp time was $91.23 \pm 26.81$ minutes. Terminal warm blood cardioplegia at $370 \mathrm{C}$ was infused just before removal of cross clamp. Left internal mammary artery (LIMA) was used as graft to left anterior descending artery, whereas saphenous venous grafts were used for remaining vessels.

IABP USE: The IABP was inserted in the presence of hemodynamic instability as a rescue support [systolic blood pressure(SBP) $<90 \mathrm{~mm}$ of $\mathrm{Hg}$, Mean arterial pressure(MAP) $<40 \mathrm{~mm}$ of $\mathrm{Hg}$, new onset RWMAs on TEE and ST-T changes on ECG ] after weaning from CBP despite maximum vasoactive drug support and optimization of preload as guided by TEE. All IABPs were inserted percutaneously via right or left femoral artery approach.

\section{Statistical Analysis:}

All statistics were performed using SPSS statistical software 20.0 version. Mean \pm standard deviations are presented.T test was used to compare hemodynamic data and a $\mathrm{P}$ value equal to or smaller than 0.05 was considered statistically significant.

\section{Results}

Clinical characteristics of the patients are presented in the [Table 1]. In total of 34 patients, 19(47.5\%) patients had an episode of myocardial infarction (MI) prior to surgery. All the patients were operated electively. Angiographically, $12(30 \%)$ patients were having severe left main (LM) with triple vessel disease (TVD), remaining 28(70\%) were of only TVD. Most of the patients 33(82.5\%) were of mild risk and $2(5 \%)$ were of high risk according to EuroSCORE II. All patients received equal number of vasoactive drugs(3) (Dobutamine $5-10 \mathrm{mcg} / \mathrm{kg} / \mathrm{min}$, Adrenaline 0.05 $0.1 \mathrm{mcg} / \mathrm{kg} / \mathrm{min}$ and Noradrenaline 0.05$0.15 \mathrm{mcg} / \mathrm{kg} / \mathrm{min}$ ).Persistence of hemodynamic instability with a forementioned vasoactive drugs and optimized preload led to IABP insertion as a rescue mechanical support. The TEE examination during the instability showed persistent RWMA and new RWMAs in all patients. All patients had significant ST-T changes during hemodynamic disturbances. The mean EF during the event was $36.26 \pm 3.66 \%$. There is significant improvement in hemodynamics post IABP insertion measured at intervals of immediately after insertion, at 15 minutes, 1 hour, 6 hours and 24 hours after IABP insertion(Table 4). The mean duration of IABP support, mechanical ventilation, length of ICU stay were shown in table 3 .There is a marginal increase in the duration of mechanical ventilation $68.99 \pm 30.93$ hours and duration of ICU stay $5.97 \pm 1.93$ days. No major complications related to IABP were recorded. There is increase in transfusion of packed cells at an average of 1.2 units, no components were transfused. An echocardiogram was done for all patients just before discharge from hospital which showed significant improvement in $E F$ ( $p$ value $=<0.0001$ ) [Table 5]. No in-hospital and 30 days mortality was recorded.

Table 1: Clinical characteristics of the patients

\begin{tabular}{|l|l|l|}
\hline Variables & No.of patients & Percentage (\%) \\
\hline Age (in Years) & 6 & \\
\hline$<50$ & 14 & 15 \\
\hline $50-59$ & 20 & 35 \\
\hline$>60$ & & 50 \\
\hline Sex & 26 & \\
\hline Males & 14 & 65 \\
\hline Females & & 35 \\
\hline Euroscore II & 35 & \\
\hline Mild risk & 5 & 87.5 \\
\hline Moderate risk & 0 & 12.5 \\
\hline High risk & & 0 \\
\hline Severity of CAD & 12 & \\
\hline LM+TVD & 28 & 30 \\
\hline TVD & 19 & 70 \\
\hline No of preop MI & 5 & 47.50 \\
\hline Incomplete revascularization & 5 & 12.50 \\
\hline CAD-coronary artery disease; LM-left main; TVD-triple vessel disease; MI-myocardial
\end{tabular}

CAD-coronary artery disease; LM-left main; TVD-triple vessel disease; MI-myocardia infraction.

Table 2: Hemodynamic data during instability

\begin{tabular}{|l|l|l|l|}
\hline Variables & \multirow{2}{*}{ Mean } & 95 \% C. I. \\
\cline { 3 - 4 } & & Lower & Upper \\
\hline SBP & $85.88 \pm 3.41$ & 84.69 & 87.07 \\
\hline MAP & $44.29 \pm 1.12$ & 43.90 & 44.68 \\
\hline HR & $99.71 \pm 2.07$ & 98.98 & 100.43 \\
\hline CVP & $8.53 \pm 0.71$ & 8.28 & 8.78 \\
\hline SPO2 & 100 & 100 & 100 \\
\hline CBP time(min) & $148.45 \pm 42.50$ & & \\
\hline Cross clamp time(min) & $91.23 \pm 26.31$ & & \\
\hline
\end{tabular}

All patients had significant ST-T changes in more than 2 leads.

SBP-systolic blood pressure in mmof $\mathrm{Hg}$; MAP-mean arterial pressure in $\mathrm{mm}$ of $\mathrm{Hg}$; $\mathrm{HR}$-heart rate in beats per minute; CVP-central venous pressure in $\mathrm{cm}$ of $\mathrm{H} 2 \mathrm{O}$.

Table 3: ICU parameters

\begin{tabular}{|l|l|l|l|}
\hline Table 3: ICU parameters & Mean & 95 \% C. I. \\
\cline { 3 - 4 } & & Lower & Upper \\
\hline $\begin{array}{l}\text { Vuriables } \\
\text { (hours) }\end{array}$ & $67.26 \pm 30.62$ & 56.58 & 77.95 \\
\hline $\begin{array}{l}\text { Duration of mechanical } \\
\text { ventilation(hours) }\end{array}$ & $68.99 \pm 30.93$ & 58.19 & 79.78 \\
\hline ICU Stay (days) & $5.97 \pm 1.93$ & 5.29 & 6.64 \\
\hline No of packed cells(units) & $1.2 \pm 0.42$ & 0.89 & 1.50 \\
\hline IABP Complications & NIL & & \\
\hline
\end{tabular}

\section{Discussion}

Mechanical circulatory assistance is used frequently to support the failing heart.IABP is usually the first choice of mechanical device used for perioperative cardiac failure. ${ }^{[17]}$ The perioperative cardiac failure and usage of IABP are increasing as patient population referred for surgical treatment increases in age and severity of preoperative LV dysfunction.In this retrospective study we evaluated the 
0

effectiveness of IABP as a rescue mechanical support in severe hemodynamic instability post CABG.The beneficial hemodynamic effects of IABP include increase in the following variables:cardiac output(CO),EF,MAP and coronary perfusion pressure(CPP). ${ }^{[18]}$ Furthermore, these benefits also include decrease in following variables:aortic systolic pressure, left ventricular end diastolic pressure (LVEDP), pulmonary capillary wedge pressure(PCWP) and left atrial pressure (LAP). ${ }^{[19]}$ As with percutaneous coronary intervention(PCI), the IABP-SHOCK II trial remains the largest RCT to date regarding the insertion of IABP before surgical revascularization. ${ }^{[20]}$ Neither SHOCK II (2012) nor SHOCK II follow up (2013) demonstrated a mortality benefit with the preprocedural placement of an IABP in the CABG cohart. ${ }^{[21]}$ Shi M,Huang J,Pang L et al ,conducted a single centered RCT involving 232 patients who have undergone off pump CABG.

\begin{tabular}{|c|c|c|c|c|}
\hline Time & SBP & MAP & HR & CVP \\
\hline $\begin{array}{l}\text { Before } \\
\text { IABP } \\
\text { insertion }\end{array}$ & $\begin{array}{l}85.88 \pm 3.41 \\
(84-87)\end{array}$ & $\begin{array}{l}44.29 \pm 1.12 \\
(43-44)\end{array}$ & $\begin{array}{l}99.71 \pm 2.07 \\
(98-100)\end{array}$ & $\begin{array}{l}8.53 \pm 0.71 \\
(8.2-8.7)\end{array}$ \\
\hline $\begin{array}{l}15 \mathrm{~min} \\
\text { after } \\
\text { IABP }\end{array}$ & $\begin{array}{l}104.35 \pm 1.81 \\
(103-104)\end{array}$ & $\begin{array}{l}56.55 \pm 1.21 \\
(56.1-56.9)\end{array}$ & $\begin{array}{l}94.91 \pm 2.86 \\
(93-95)\end{array}$ & $\begin{array}{l}5.03 \pm 0.72 \\
(4-5)\end{array}$ \\
\hline $\begin{array}{l}1 \mathrm{hr} \text { after } \\
\text { IABP }\end{array}$ & $\begin{array}{l}112.53 \pm 1.83 \\
(111-113)\end{array}$ & $\begin{array}{l}61.15 \pm 1.43 \\
(60-61)\end{array}$ & $\begin{array}{l}88.12 \pm 1.98 \\
(87-88)\end{array}$ & $\begin{array}{l}4.74 \pm 0.62 \\
(4.5-4.9)\end{array}$ \\
\hline $\begin{array}{l}6 \mathrm{hrs} \\
\text { after } \\
\text { IABP }\end{array}$ & $\begin{array}{l}115.68 \pm 2.92 \\
(114-116)\end{array}$ & $\begin{array}{l}67.41 \pm 1.52 \\
(66-67)\end{array}$ & $\begin{array}{l}99.62 \pm 2.5 \\
(98-100)\end{array}$ & $\begin{array}{l}4.65 \pm 0.69 \\
(4.4-4.8)\end{array}$ \\
\hline $\begin{array}{l}24 \mathrm{hrs} \\
\text { after } \\
\text { IABP }\end{array}$ & $\begin{array}{l}118.71 \pm 1.17 \\
(118-119)\end{array}$ & $\begin{array}{l}70.53 \pm 1.16 \\
(70.1-70.9)\end{array}$ & $\begin{array}{l}80.38 \pm 1.07 \\
(80-80.7)\end{array}$ & $\begin{array}{l}4.79 \pm 0.69 \\
(4-5)\end{array}$ \\
\hline$P$ value & 0.0001 & 0.0001 & 0.0001 & 0.0001 \\
\hline
\end{tabular}

Table 5: Comparision of Ejection Fraction (EF\%) during IABP insertion and at the discharge from hospital.

\begin{tabular}{|l|l|l|}
\hline EF\% & MEAN & P VALUE \\
\cline { 1 - 2 } EF\% during IABP insertion & $36.26 \pm 3.66$ & $<0.0001$ \\
\cline { 1 - 2 } $\begin{array}{l}\text { EF\% before discharge from } \\
\text { hospital }\end{array}$ & $50.56 \pm 2.58$ & \\
\hline
\end{tabular}

Of that 232 patients, 107 patients had preoperative IABP insertion since they are categorised as high risk. The results showed a decrease in mortality in IABP group (1.9\% vs $4 \%$ in control group with $\mathrm{p}$ value $<0.05)$ compared to non IABP group. This investigation concluded that the preoperative placement of IABP decreases mortality in off pump CABGs. ${ }^{[22]}$ In our study, the IABP was used as a rescue modality of support immediately post CPB. We did not know the exact cause of hemodynamic disturbances since many factors like graft dysfunction, poor quality of conduits, preoperative LV dysfunction, CPB induced myocardial dysfunction; all play a role in perioperative hemodynamic disturbances. After maximal vasoactive drugs and optimizing preload we chose to initiate IABP support for hemodynamic instability. After the initiation, all the patients showed a significant improvement in hemodynamics. No patient required further augmentation of vasoactive drugs once the IABP was initiated. In a study conducted by Hilmi Tokmakoglu, Bora Farsak, Serdas Gunaydin et al, showed IABP is effective in patients who are unable to wean from
CPB after CABG surgery.

Of the total 69 patients of their study,59(85.5\%) could be weaned from CPB successfully with IABP support. The average in hospital mortality in their study of the patients treated with IABP was $33 \%$.In our study, we did not have any mortality or major complications related to IABP. The three recent ,meta analyses regarding use of IABP in high risk CABG surgeries, ${ }^{[23-25]}$ showed a mortality benefit in CABG with IABP but in most of the RCTs included in these meta analyses, IABP insertion was done before surgery. Most of the studies conducted in cardiac surgery on IABP insertion were of in preoperative high risk elective groups. Our study showed a significant improvement in hemodynamics and no mortality when IABP was used as rescue measure intraoperatively during severe hemodynamic instability.

Unlike cardiogenic shock associated with acute MI where the role of IABP is controversial according to current literature, cardiogenic shock or pump failure associated with cardiac surgery has various contributing etiological factors. Even though many studies have showed a mortality benefit for usage of IABP in cardiac surgery, ${ }^{[26,27]}$ there is down grading of recommendations from class I to class II for IABP usage by American Heart Association/American College of Cardiology (AHA/ACC).A large multicentric RCT is needed to see that efficacy of IABP support as a rescue measure in pump failure associated with cardiac surgery.

\section{Conclusion}

In a retrospective analysis of 34 patients, who have undergone conventional $\mathrm{CABG}$ and received IABP as a rescue mechanical support for severe hemodynamic disturbances,showed: significant improvement in hemodynamics post IABP insertion; Improvement in EF at discharge from hospital; No mortality at discharge from hospital and 30 days postoperatively.

Limitations: It is a retrospective analysis of small sample single centre study. The exact mortality benefit could not be studied as there is no control group.

\section{References}

1. Perera D, Lumley M, Pijls N, Patel MR. Intra-aortic balloon pump trials: questions, answers, and unresolved issues. Circulation: Cardiovascular Interventions. 2013 Jun;6(3):317-21.

2. Holger Thiele, Gerhard Schuler, Cardiogenic shock: to pump or not to pump?, European Heart Journal, Volume 30, Issue 4, February 2009, 389-390.

3. Taylor J. Controversies in acute cardiovascular care: cardiogenic shock. European heart journal. $2014 \mathrm{Jan} ; 35(2): 61-2$.

4. Antman EM, Anbe DT, Armstrong PW, Bates ER, Green LA, Hand M, Hochman JS, Krumholz HM, Kushner FG, Lamas GA, Mullany CJ. ACC/AHA guidelines for the management of patients with ST-elevation myocardial infarction-executive summary: a report of the American College of Cardiology/American Heart Association Task Force on Practice Guidelines (Writing Committee to Revise the 1999 Guidelines for the Management of Patients With Acute Myocardial Infarction). Journal of the American College of Cardiology. 2004 Aug 4;44(3):671719.

5. Authors/Task Force Members, Van de Werf F, Bax J, Betriu A, Blomstrom-Lundqvist C, Crea F, Falk V, Filippatos G, Fox K, Huber K, Kastrati A. Management of acute myocardial infarction in patients presenting with persistent ST-segment elevation: the Task Force on the Management of ST-Segment Elevation Acute Myocardial Infarction of the European Society of Cardiology. European heart journal. 2008 Dec 
$1 ; 29(23): 2909-45$.

6. Roffi M, Patrono C, Collet JP, Mueller C, Valgimigli M, Andreotti F, Bax JJ, Borger MA, Brotons C, Chew DP, Gencer B. 2015 ESC Guidelines for the management of acute coronary syndromes in patients presenting without persistent ST-segment elevation: Task Force for the Management of Acute Coronary Syndromes in Patients Presenting without Persistent ST-Segment Elevation of the European Society of Cardiology (ESC). European heart journal. 2016 Jan 14;37(3):267-315.

7. Hiratzka LF, Bakris GL, Beckman JA. O'Gara PT, Kushner FG, Ascheim DD, et al. 2013 ACCF/AHA guideline for the management of ST-elevation myocardial infarction: executive summary: a report of the American College of Cardiology Foundation/American Heart Association Task Force on Practice Guidelines. J Am Coll Cardiol 2013; 61: 485-510, http://dx. doi. org/10.1016. Journal of the American College of Cardiology. 2013;62(11).

8. Amsterdam EA, Wenger NK, Brindis RG, Casey DE, Ganiats TG Holmes DR, Jaffe AS, Jneid H, Kelly RF, Kontos MC, Levine GN. 2014 AHA/ACC guideline for the management of patients with nonST-elevation acute coronary syndromes: a report of the American College of Cardiology/American Heart Association Task Force on Practice Guidelines. Journal of the American College of Cardiology. 2014 Dec 23;64(24):e139-228.

9. Task Force on the Management of ST-Segment Elevation Acute Myocardial Infarction of the European Society of Cardiology (ESC ESC Guidelines for the management of acute myocardial infarction in patients presenting with ST-segment elevation. Eur Heart J. 2012 Oct;33(20):2569-619.

10. Christenson JT, Simonet F, Badel P, Schmuziger M. The effect of preoperative intra-aortic balloon pump support in patients with coronary artery disease, poor left-ventricular function (LVEF < 40\%), an hypertensive LV hypertrophy. Thorac Cardiovasc Surg. 1997;45:60-64. doi: $10.1055 / \mathrm{s}-2007-1013688$

11. Christenson JT, Simonet F, Badel P, Schmuziger M. Optimal timing of preoperative intraaortic balloon pump support in high-risk coronary patients. Ann Thorac Surg. 1999;68:934-939.

12. Elahia$$
\mathrm{M}
$$

G.K.ChettyaR.KirkeaT.AzeembR.HartshorneaT.J.SpytaComplications Related to Intra-aortic Balloon Pump in Cardiac Surgery: A Decade Later.Eur j vascendovasc surg 2005;29:591-4.

13. Miceli A, Fiorani B, Danesi TH, Melina G, Sinatra R. Prophylactic intra-aortic balloon pump in high-risk patients undergoing coronary artery bypass grafting: a propensity score analysis. Interact CardioVasc Thorac Surg. 2009;9(2):291-4

14. Elefterades JA, Kron IL.CABG in advanced left ventricular dysfunction. Cardiol Clin 1995; 13:35-42.

15. Kaul TK, Agnihotri AK, Fields BL, Riggins LS, Wyatt DA, Jones CR. Coronary artery bypass grafting in patients with an ejection fraction of twenty percent or less. J Thorac Cardivasc S URG 1996;111:1001-12.

16. Dietl CA, Berkheimer MD,Woods EL,Gilbert CL,Pharr WS,Benoit CH. Efficacy and cost effectiveness preoperative IABP in patients with ejection fraction of 0.25 or less.Ann horac Surg 1996;62:401-9.

17. Naumheim KS,Swartz MT,Pennington DG,et al. Intra arotic ballon pumping in patients requiring cardiac operations. Risk analysis and longterm follow up. J Thorac Cardiovasc Surg 1992; 104:1654-61.

18. van Nunen LX, Noc M, Kapur NK, Patel MR, Perera D, Pijls NH. Usefulness of intra-aortic balloon pump counterpulsation. The American Journal of Cardiology. 2016 Feb 1;117(3):469-76.

19. Zaky A. Pro: Prophylactic preoperative use of an intra-aortic balloon pump is indicated in high-risk coronary patients undergoing coronary artery bypass grafting. Journal of cardiothoracic and vascular anesthesia. 2015 Apr 1;29(2):532-3.

20. Thiele H, Zeymer U, Neumann FJ, Ferenc M, Olbrich HG, Hausleiter J, de Waha A, Richardt G, Hennersdorf M, Empen K, Fuernau G. Intraaortic balloon counterpulsation in acute myocardial infarction complicated by cardiogenic shock (IABP-SHOCK II): final 12 month results of a randomised, open-label trial. The Lancet. 2013 Nov 16;382(9905):1638-45.

21. Thiele H, Zeymer U, Neumann FJ, Ferenc M, Olbrich HG, Hausleiter J, de Waha A, Richardt G, Hennersdorf M, Empen K, Fuernau G. Intraaortic balloon counterpulsation in acute myocardial infarction complicated by cardiogenic shock (IABP-SHOCK II): final 12 month results of a randomised, open-label trial. The Lancet. 2013 Nov 16;382(9905):1638-45.

22. Shi M, Huang J, Pang L, Wang Y. Preoperative insertion of an intraaortic balloon pump improved the prognosis of high-risk patients undergoing off-pump coronary artery bypass grafting. Journal of International Medical Research. 2011 Aug;39(4):1163-8.

23. Achour H, Boccalandro F, Felli P, Amirian J, Uthman M, Buja M, Smalling RW. Mechanical left ventricular unloading prior to reperfusion reduces infarct size in a canine infarction model. Catheterization and cardiovascular interventions. 2005 Feb;64(2):182-92.

24. Zangrillo A, Pappalardo F, Dossi R, Di Prima AL, Sassone ME, Greco T, Monaco F, Musu M, Finco G, Landoni G. Preoperative intra-aortic balloon pump to reduce mortality in coronary artery bypass graft: a meta-analysis of randomized controlled trials. Critical Care. 2015 Dec;19(1):10.

25. Pilarczyk K, Boening A, Jakob H, Langebartels G, Markewitz A, Haake N, Heringlake M, Trummer G. Preoperative intra-aortic counterpulsation in high-risk patients undergoing cardiac surgery: a meta-analysis of randomized controlled trials. European Journal of Cardio-Thoracic Surgery. 2015 Aug 5;49(1):5-17.

26. Theologou T, Bashir M, Rengarajan A, Khan O, Spyt T, Richens D, Field M. Preoperative intra aortic balloon pumps in patients undergoing coronary artery bypass grafting. Cochrane Database of Systematic Reviews. 2011(1).

27. Wan YD, Sun TW, Kan QC, Guan FX, Liu ZQ, Zhang SG. The effects of intra-aortic balloon pumps on mortality in patients undergoing highrisk coronary revascularization: a meta-analysis of randomized controlled trials of coronary artery bypass grafting and stenting era. PLoS One. 2016 Jan 19;11(1):e0147291.

Copyright: () the author(s), publisher. Academia Anesthesiologica International is an Official Publication of "Society for Health Care \& Research Development". It is an open-access article distributed under the terms of the Creative Commons Attribution Non-Commercial License, which permits unrestricted non-commercial use, distribution, and reproduction in any medium, provided the original work is properly cited.

How to cite this article: Harish R, Rajitha A, Kodandapani C. Effectiveness of Intra- Aortic Ballon Pump (IABP) Insertion as Rescue Mechanical Support for on Pump Coronary Artery Bypass Surgery Patients with Persistent Intraoperative Hemodynamic Instability.. Acad. Anesthesiol. Int. 2019;4(2):155-158.

DOI: dx.doi.org/10.21276/aan.2019.4.2.35

Source of Support: Nil, Conflict of Interest: None declared. 